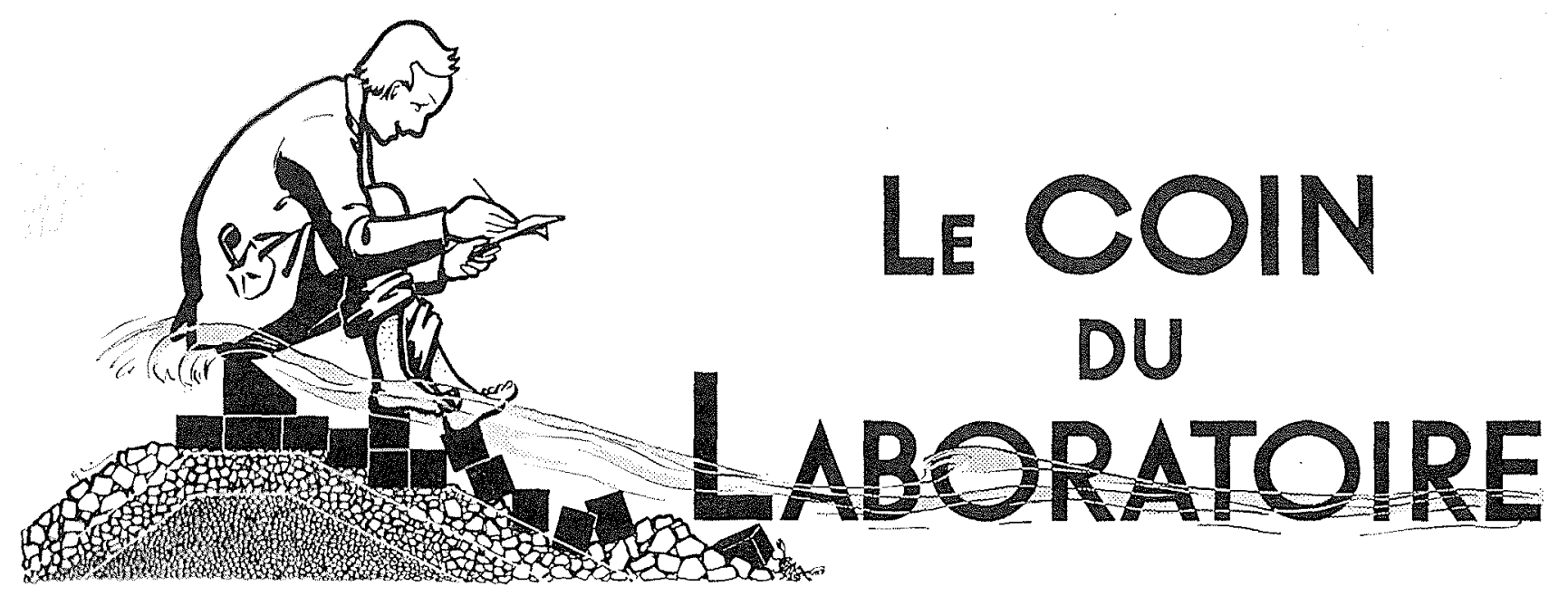

\title{
Appareil générateur de vagues flottant
}

\author{
English text, p. 868 .
}

Certaines études sur modèle réduit amènent parfois à envisager la mise en ouvre de tout un équipement matériel qui est hors de proportion avec les moyens dont dispose habituellement un Laboratoire et qui, en tout état de cause, constitue une source de difficultés, de pertes de temps ct, en lin de compte, de moindre efficacité. Nous allons voil que, dans certains cas, il est possible, au prix d'une étude préliminaire judicieuse, de réduire considérablement ou même d'éviter complètement ces difficultés.

L'étude d'un port maritime sur modèle réduit peut nécessiter la construction puis' l'emploi d'un appareil générateur de vagues de grandes dimensions. Or, il est exceptionnel que les essais ne portent que sur une seule direction de houle; on se trouve donc amené à déplacer l'appareil sur le modele toules les fois que l'on désire modifier l'orientation des houles étudiées.

Une telle manouvre est assez facile lorsqu'on l'exécute dans un petit modèle peu profond et sur un appareil à vagues de quelques dizaines de $\mathrm{kg}$. Sur un grand modèle, il n'en est pas de même : la profondeur d'eau est plus grande et l'appareil à vagues pèse facilement plusieurs centaines de $\mathrm{kg}$. Une première općration consiste à libérer l'appareil de sa fixation sur le fond du bassin; ceci oblige presque toujours à vider complètement la maquetle, afin d'atteindre commodément les boulons d'ancrage. La seconde phase des opérations - le transport du batteur jusqu'à sa nouvelle position - est au-dessus des possibilités de l'équipe d'essais', qui se voit contrainte de faire appel à une équipe de manœuvres. L'appareil une fois déposé à son nouvel emplacement, il reste à le boulonner à nouveau avant de remplir la maquette, puis de régler le niveau et enfin de reprendre les essais.

On conçoit sans difficulté qu'il y ait là de quoi se donner beaucoup de peine et de quoi perdre un temps précieux. 
Le Laboratoire Dauphinois d'Hydraulique Neyrpic a mis au point un dispositif qui évite de tels inconvénients. Le principe consiste simplement à faire flotter l'appareil à vagues pour le transporter d'un point à un autre. Au lieu d'être installé sur un bâti en f'ers profilés, l'ensemble du volet, de son moteur et de ses organes de commande repose sur une poutre eaisson très rigide qui forme flotteur. Normalement, ce caisson est plein d'eau et l'appareil est maintenu en position sur le fond du modèle par le seul effet de son poids (fig. 1).

Si l'on désire changer l'orientation des houles émises, et, par conséquent, celle du batteur, il suffit de brancher le réseau d'air comprimé du laboratoire sur une prise prévue à cet effet, au sommet de la poutre-caisson. L'eau ayant été ainsi chassée, l'appareil se met à flotter, et il est très aisé de l'amener sur une autre position où il est échoué à nouveau (fig. 2).

L’opération peut être menćc à bien en quel- ques minutes, sans difficulté et sans effort. Avec la disposition classique, c'était plusieurs heures, sinon une demi-journée, perdues en manouvres longues et pénibles.

La poutre-caisson n'a pas seulement les avantages pratiques considérables signalés ci-dessus. On a pu en retirer des avantages d'ordre hydraulique particulièrement précieux.

On sait que, sur un modèle maritime d'études de houle, on a tout intérèt à opérer avec des houles aussi pures que possible. Il convient donc d'éliminer au maximum les houles parasites et, en particulier, celle qui est émise par la face arrière du batteur : les modéles portuaires classiques comportent, à cet effet, en arrière des diverses positions occupées par le batteur, des' plages amortisseuses. Grâce à un profilage convenable (cf. fig. 1), il a été possible de faire de la poutre-caisson un amortisseur préliminaire suffisamment efficace pour réduire, dans une très

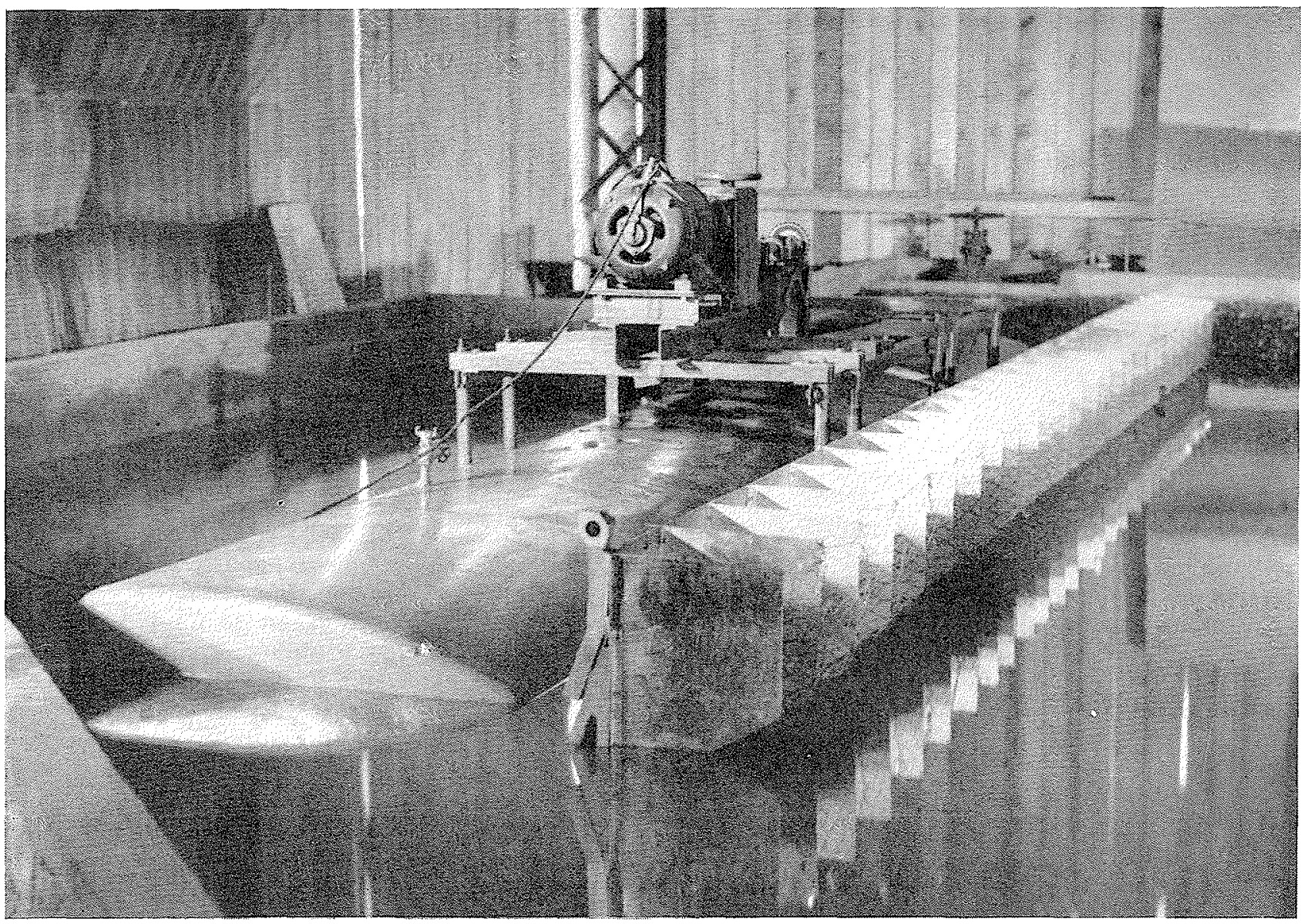

Futi. 1. - Lappareil à vagues repose sur le fond du modele où le niveau d'an a éte abaissé de façon à ce que les organes essentiels puissent être vus.

Wave machine resting on model bed; the uvater-level has been lowered to show the main parts of the apparatus. 


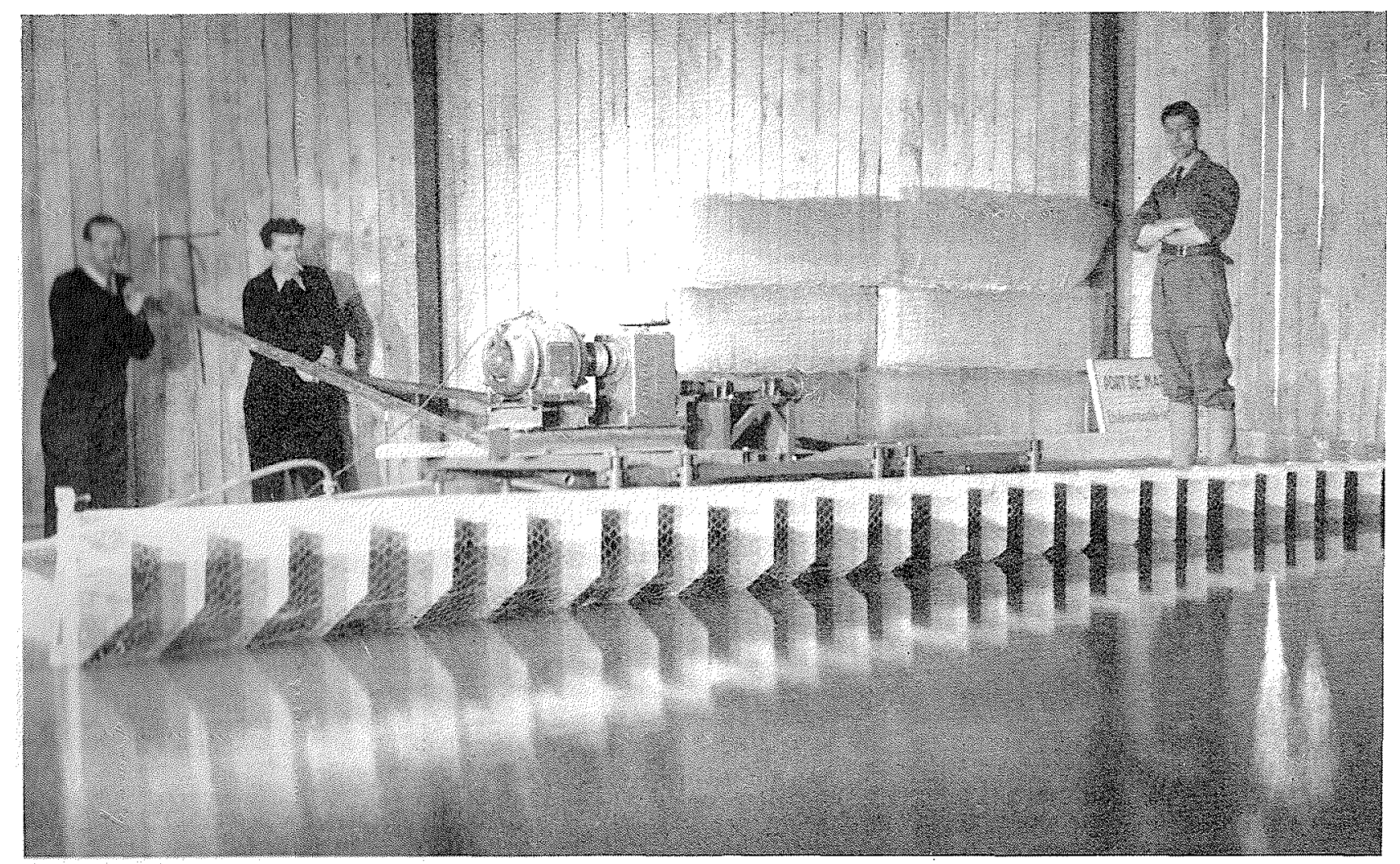

Thu. 2. -... Ifappareil a vagues folte et est amené vers une nouvelle position. Wave machine afloat and being moved lo new position.

notable proportion, la largeur des plages amortisseuses, qui ne jouent plus désormais qu'un ròle complémentaire. Il en résulte, bien entendu, une diminution appréciable de l'encombrement el, par conséquent, du coùt, toujours élevé, de l'ensemble du modèle.

Le fait est qu'un tel appareil est en service depuis plusieurs années au Laboratoire Neyrpic, et qüil s'est tonjours parfaitement comporté.

Cect montre, une fois de plus, que beaucoup de difficultés auxquelles on se heurte dans les Laboratoires d'Hydraulique peuvent être considérablement réduites au prix d'artifices relativement simples, aussi bien dans leur principe que dans leur réalisation. Les modèles coûtent moins cher, les essais sont moins longs et la plus grande souplesse, donnée à l'outil d'investiggation, permet d'augmenter à la fois le champ et la précision des résultats expérimentaux.

Laboratoire DauphinoIs d'Hydraunigue. (Neyrpic, Grenoble.)

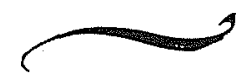




\title{
LABORATORY PRACTICE
}

\section{Floating wave machine}

\author{
Figures in French text, p. 865. \\ Texte français, p. 865.
}

The scale model study of a sea harbour may entail the construction and the use of a large wave machine. It is, moreover, exceptional when tests are made with waves coming from only one direction, and it is therefore necessary to change the position of the wave machine on the model whenever the wave direction is to be altered.

This is fairly easy on a small, shallow model with a wave machine weighing some 30 or $40 \mathrm{~kg}$. However, such is not the case in a large model; the water is deep and the wave machine may weigh up to 500 or $600 \mathrm{~kg}$. The apparatus must first be unfixed from the floor of the model; this almost always entails emptying the model completely in order to get at the bolts. The wave machine inusl then be moved to its position; this cannot be done by the regular test team and a special, heavy labour squad is needed. Once the machine is in its new position, it must again be bolted to the floor before the water can be let into the model; the water-level must then be checked and, finally, the tests may be resumed.

It is easily seen that these mulliple operations entail much waste of time and unnecessary work.

The Neyrpic Hydraulic Research Laboratory has developed an apparatus which overcomes these difficulties. The principle consists simply in floating the wave machine in order to move if from place to place. Instead of being on an iron girder base, the blade, its motor and the controls are on a rigid floating bridge. The float of this bridge is normally full of water and the wave machine is held down on the bottom of the model simply by ils own weight (fig. 1).

If the wave direction, and hence the position of the apparatus, is to be changed, one has but to connect up the Laboratory's compressed air circuit to the float of the bridge (an air inlet valve is provided on the upper part of the float). Once the float has thus been cmptyed of water and the apparatus is afloat, it is easy matter to move it to a new position, where water is once again let into the float (fig. 2).

This operation can be carried out in a few minutes without any difficulty or waste of time, whereas with the standard type of wave machine this manwuvre was long and tiresome and required several hours or even half a day to carry out.

The practical advantages of the floating bridge which are mentioned above are not the only ones, and this device has other advantages which are of particular interest from the hydraulic view-point.

On a sea model for the investigation of waves, it is desirable to produce waves that are as pure as possible. Parasitic waves should therefore be eliminated as for as is possible, and, in particular, those which reflect off the rear face of the wave machine. It is for this reason that standard harbour models have non-reflecting banks placed behind the various positions in which the wave machine may be placed. By shaping the floating bridge correctly (see fig. 1), it was possible to make it act as a preliminary damper which was of sufficient efficiency to enable the width of the non-reflecting banks to be considerably reduced; these latter then fulfill only a complementary role, and the net result is an appreciable decrease in the overall dimensions, whence in the necessarily high cost of the model as a whole.

$A$ wave machine such as this has been in use for several years now at the Neyrpic Laboratory and has always operated satisfactorily.

It can thus be seen that many of the difficulties which arise in hydraulic research laboratories can be overcome to a considerable extent by means of arrangements of relatively simple design and construction. Models are less costly, tests are shorter, and the greater adaplability of the testing equipment increases both the scope and the accuracy of the experimental results.

Neyrpic Hydraulic Laboratory. Grenoble 